\title{
EXPLORING DYNAMIC CAPABILITIES, INTELLECTUAL CAPITAL AND INNOVATION PERFORMANCE RELATIONSHIP: EVIDENCE FROM THE GARMENT MANUFACTURING
}

\author{
Wendra WENDRA ${ }^{1}$, Ernie Tisnawati SULE$^{2}$, Joeliaty JOELIATY ${ }^{3}$, Yudi AZIS ${ }^{4}$ \\ ${ }^{1}$ PPM School of Management, Jakarta, Indonesia \\ ${ }^{2,3,4}$ Faculty of Economics and Business, Universitas Padjadjaran, Bandung, Indonesia \\ E-mails: ${ }^{1}$ wen.ppm@gmail.com (corresponding author); ${ }^{2}$ ernie.tisnawati.fe@unpad.ac.id;

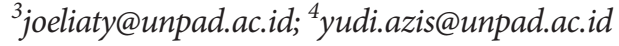

Received 30 November 2018; accepted 25 February 2019

\begin{abstract}
The notions of dynamic capabilities, intellectual capital, and innovation performance have been examined in many competitive advantage scholarly papers. However, there have been small numbers of management studies that consider the link of dynamic capabilities and intellectual capital in respect of innovation performance. Previous studies tend to argue that dynamic capabilities played a mediator or moderator role on intellectual capital and innovation performance linkage. Therefore, this study seeks to propose a new perspective that dynamic capabilities are the antecedents of intellectual capital leading to innovation performance. Thus, the rationale for this study is to propose a conceptual model and to provide empirical support on the mediator role of intellectual capital in dynamic capabilities and innovation performance linkage. By using accidental and snowballs sampling techniques, this study distributed questionnaires to 297 small and medium enterprises of the garment manufacturing in Indonesia. Partial least square offers the main statistics methodology for data analysis. Results show that dynamic capabilities had a significant influence on intellectual capital and innovation performance. Moreover, intellectual capital partially mediated dynamic capabilities' influence on innovation performance. Therefore, it is expected that organisations should grow, implement and maintain their dynamic capabilities in order to improve their intellectual capital and innovation outcomes. Lastly, some future studies are suggested.
\end{abstract}

Keywords: competitive advantage, dynamic capabilities, garment manufacturing, innovation performance, intellectual capital, partial least square, small and medium enterprises.

JEL Classification: M10, M12, O31, O34.

\section{Introduction}

Facing a more intense business competition, and rapidly changing consumers' preferences, the organisations need to find new ways of maintaining their existence. With this in mind, the conception of dynamic capabilities emerges as critical factors to ensure organisational growth and competitiveness (Eisenhardt and Martin 2000, Zahra et al. 2006, Zheng et al. 2011, Chien and Tsai 2012, BabelyteLabanauske and Nedzinskas 2017). Since it was first introduced more than 20 years ago by Teece et al. (1997), the importance of dynamic capabilities has attracted many responses from academics (Eisenhardt and Martin 2000, Zahra et al. 2006, Ambrosini and Bowman 2009, Barreto 2010, Li and Liu 2014) and practitioners. Several theoretical works have been written to uncover this thought (Eisenhardt and Martin 2000, Winter 2003, Teece 2007).

The academic discussion on competitive advantage also emphasised the critical function of knowledge stock (Chien and Tsai 2012) or intellectual capital (Castro et al. 2013, Wang and Chen 2013). It is considered as the intangible asset (Petty and Guthrie 2000, Bueno et al. 2004, Chen et al. 2005) that critically helps organisations to achieve

Copyright $\odot 2019$ The Authors. Published by VGTU Press.

This is an Open Access article distributed under the terms of the Creative Commons Attribution License (http://creativecommons.org/licenses/by/4.0/), which permits unrestricted use, distribution, and reproduction in any medium, provided the original author and source are credited.. 
competitive advantage (Joeliaty 2012) and sustainable success (Subramaniam and Youndt 2005).

At the same time, several scholarly articles also discuss the role of innovation for achieving organisational competitive advantage. Various organisational activities in designing, producing, marketing and distributing of its products are aimed at fulfilling market demands. Since each activity may lead to specific cost position and/or product differentiation, therefore, the unique pricing or products can create a competitive advantage. Hence, innovation is a way to create organisational competitiveness (Azis et al. 2014).

Even though some efforts have been undertaken to comprehend the above mentioned notions of dynamic capabilities, intellectual capital, and innovation, further efforts focused on empirical analyses of the interplay among those variables are needed (Wu et al. 2007, Hsu and Wang 2012, Han and Li 2015, Ansari et al. 2016). Previous works concluded that dynamic capabilities mediated intellectual capital impacts on innovation performance (e.g. Hsu and Wang 2012, Han and Li 2015, Ansari et al. 2016). Differently, Wu et al. (2007) concluded that dynamic capabilities moderated the causal relationship between intellectual capital and innovation performance. However, Ambrosini and Bowman (2009) argued that organisational value creation is the product of dynamic capabilities through resource base. In other words, Ambrosini and Bowman (2009) proposed that the resource base was the direct product of dynamic capabilities. In accordance, Teece et al. (1997) and Teece (2009) described dynamic capabilities as organisational competencies to develop, mobilise and maintain its intangible assets in supporting sustainable organisational performance. Taking on the argument of Ambrosini and Bowman (2009), Teece et al. (1997) and Teece (2009) above, this study proposes dynamic capabilities as the antecedent of intellectual capital leading to innovation performance.

In addition, previous studies on dynamic capabilities, intellectual capital and innovation performance were conducted in the technology-based (Wu et al. 2007, Hsu and Wang 2012), petrochemical (Ansari et al. 2016), and biochemical firms, mostly in large organisations and in developed countries (Protogerou et al. 2011). However, previous research rarely consider the more traditional sector, such as garment manufacturing in small and medium enterprises (SMEs) of a developed country. In fact, the business environment of garment manufacturing sector is very competitive, highly volatile and unpredictable (Bruce et al. 2004, Nayak and Padhye 2015). The garment manufacturing continuously needs to deliver high-quality products, develop new brands, enter or create new markets and respond to a variety of customer expectation (Kapelko and Oude Lansink 2014), since its products have a short life cycle. Sales are very much affected by session, weather, promotion, advert, and marketing, and also economic and social factor
(Fumi et al. 2013). Those uncertain business environment features require garment manufacturing to have dynamic capabilities (Wang 2016). Furthermore, since the garment manufacturing can be categorised as technology receiver sector (Pavitt 1984), it relies heavily on the intangible asset (Kapelko and Oude Lansink 2014), which is argued never to run out (Azis et al. 2017) to generate innovation. Thus, investment in intangible capital is crucial for the garment manufacturing (Stengg 2001). As for SMEs of garment manufacturing, the challenges are intensified by the fact that SMEs are mostly having limited internal resources (Nieto and Santamaría 2010). While large firms can rely on their internal capacity to boost innovation, SMEs need to manage collaboration with their parties through the development of relational capital (Iturrioz et al. 2015).

Those substantial research scarcities demand for further studies. Accordingly, the rationale for this study is to develop a conceptual model and provide evidence in the under-developed literature on dynamic capabilities and intellectual capital relationship in predicting innovation performance in SMEs of garment manufacturing. Notably, this study is expected to contribute to a broader knowledge of the extent intellectual capital that can mediate dynamic capabilities and innovation performance relationship.

This study took place in the Indonesian SMEs of garment manufacturing. The availability of raw material with economical price is a big challenge for the Indonesian garment manufacturing to develop the business. The upstream sector of the Indonesian garment manufacturing relies heavily on the imported raw materials, which turns the downstream sector to become volatile, due to exchange rate fluctuation. Besides, apparels produced by SMEs of garment manufacturing face a direct competition with finished imported goods from a low-cost producing country such as China, and products of local large garment manufacturing. Those issues escalate the importance of dynamic capabilities, intellectual capital and innovation in Indonesian SMEs of garment manufacturing.

In order to reach the objective of the study, the next part of the paper provides literature review and hypotheses. Then, the paper presents the research method, the result, discussion, and conclusions.

\section{Literature review and hypotheses}

\subsection{Dynamic capabilities}

In a highly competitive business environment, possessing resources are inadequate to make organisation stays ahead of its competitor (Eisenhardt and Martin 2000, Wang and Ahmed 2007, Li and Liu 2014). The organisation is required to have the capacity to mix, upgrade and redesign its inner and outer competencies (Teece et al. 1997). In their paper, Schumpeter (1934) and Penrose (1959) provide 
the conceptual foundations of the dynamic capabilities. However, Teece et al's (1997) concept on dynamic capabilities regarded as the influential pioneer paper on the topic. Teece et al's (1997) work has extensively been cited and has triggered other scholars to redefine the concept of dynamic capabilities (Breznik and Hisrich 2014).

Eisenhardt and Martin (2000) define dynamic capabilities as a series of activities to utilise, combine, reconfigure and mobilise resources. Dynamic capabilities might be specific in the element, but generally have similar features. As organisational best practices, dynamic capabilities can be implemented in various organisations. Other scholars, such as Zollo and Winter (2002) describe dynamic capabilities as "learned and stable pattern of collective activity" to change their daily activities in order to enhance performance. In contrary, Zahra et al. (2006) propose the meaning of dynamic capabilities from the entrepreneurial point of view as organisational abilities to reconfigure resources and routines by principal decision maker's vision.

Ambrosini and Bowman (2009) argue that to have a better understanding of what dynamic capabilities are about; there is a need to differentiate several types of capabilities. The first type of capabilities is valuable, rare, imperfectly imitable and non-substitutable (VRIN) resources, organisational process and management decision regarding organisational resources and process. This type is the necessary foundation for the organisation to run its routines. It is also labelled as first-category capability (Collis 1994), first-level capability (Danneels 2002), zero-level capability (Winter 2003), substantive capability (Zahra et al. 2006), resource base (Ambrosini and Bowman 2009), or growth capabilities (Koryak et al. 2015). From knowledge-based view (KBV) perspective, this type of capabilities is related to intellectual capital and the management process (Koryak et al. 2015). However, possessing zero-level capability will not be able to support an organisation to gain a long-term sustainable competitive advantage (Ambrosini and Bowman 2009). Zero-level capability will only enable the organisation to create the same product, scale and consumer all the time (Winter 2003). It will only lead to a short-term return, due to limited attention to the external environment (Chien and Tsai 2012, Li and Liu 2014). Therefore, the organisation needs to have the next type of capabilities.

The second type of capabilities is the one that supports dynamic improvement through the creation, modification, or enlargement of the VRIN resources. This type is also called second category (Collis 1994), zero-level capability (Danneels 2002), first-order capability (Winter 2003), dynamic capabilities (Teece et al. 1997, Zahra et al. 2006), second order (Danneels 2008), or incremental capability (Ambrosini and Bowman 2009). Dynamic capabilities are the capabilities that allow the organisation to revitalise its zero-level capabilities. Subsequently, the organisation will gain long-term benefit (Protogerou et al. 2011).
Barreto (2010) describes dynamic capabilities as the inclination of the organisation to 1. identify opportunities and threats, 2. compose well-timed judgment, 3. construct market-oriented conclusion, and 4. modify its resource. Li and Liu (2014) question the third dimensions of Barretto's (2010) dynamic capabilities and argue that in reality, market-oriented decisions cannot be implemented purely due to limited resources access. However, Li and Liu (2014) support the rest of Barretto's (2010) the dynamic capabilities dimensions.

This study adopted the construct of dynamic capabilities as proposed by Barreto (2010) and comprehended by $\mathrm{Li}$ and Liu (2014) that dynamic capabilities are organisational abilities to solve problem systematically through strategic sensing for opportunities and threats, on-time decision making and change the implementation to advance organisational performance. Thus, the dynamic capabilities of this study consist of three dimensions: 1. strategic sensing (SS), 2. decision making (DM), and 3. change implementation (CI). Strategic sensing is related to organisational activities of assessing business opportunities and threats. Decision making is about making a timely decision towards results of strategic sensing activity. Change implementation is about organising internal resource to support organisational action.

\subsection{Intellectual capital}

Since the work of Edvinsson and Malone (1997) in Skandia is to portray the accurate value of the organisation, the concept of intellectual capital has attracted many scholars (Survilaite et al. 2015). Intellectual capital is the intangible resource that is difficult to measure. However, it is critical to achieve organisational value added (Mačerinskienè and Survilaitè 2011).

Intellectual capital is a static aspect of knowledge (Kianto et al. 2014, Wu and Chen 2014, Marzo et al. 2016). It is a passive, measurable, classified, potentially having the ability to generate organisational value creation. Intellectual capital is the collective knowledge used in production activities (Kianto et al. 2014). It is the representation of knowledge, skill, experience, customer relation, information, database, organisational structure, innovation, social value, belief and trustworthiness (Khalique et al. 2015).

Singh and Rao (2016) state that intellectual capital is the collection of knowledge stocks, which exist in within and outside the organisation. The majority of scholarly articles describe intellectual capital in a tripartite model using human, structural and relational capital (Buenechea-Elberdin 2017). Human capital is about the employees' know-how, either tacit or explicit. It includes the ability to renew knowledge for the organisation (Engelman et al. 2017). Structural capital is the organisational know-how in the form of organisational process and data flow (Hsu and Wang 2012). 
Relational capital is related to knowledge derived from organisational interaction with external parties (Cabrita and Bontis 2008, Engelman et al. 2017). Recently, scholars have proposed entrepreneurial capital as an element of intellectual capital (Hussinki et al. 2017). Entrepreneurial capital is related to entrepreneur behaviour performed by organisational members (Inkinen et al. 2017).

This study proposes intellectual capital as intangible resource that have the potential to support organisational effort to achieve superior performance. It consists of 1 . human capital (HC), 2. structural capital (SC), 3. relational capital (RC) and 4. entrepreneurial capital (EC).

\subsection{Innovation performance}

Innovation is the production of new idea generation (Gupta et al. 2007), development and execution of a new thing (Anderson et al. 2014), from the customer perspective (Schumpeter 1934). Innovation emerges whenever people add value towards goods, services, process, marketing, delivery system, and policy, not only for the benefit of the organisation but also for stakeholders (Müller et al. 2009). Innovation aims at improving the internal business structure and process and creating goods and services demanded by the market (du Plessis 2007).

New product and method development will lead to innovation (Yuan et al. 2013). Innovation is the product, process, marketing, and organisational method implementation that is new and significantly changing from the previous state (OECD 2005). Innovation is a multidimensional process and multi-sourced, which is derived from the interaction between the individual and the organisation (Suroso and Azis 2015). Other scholars, Rijsdijk et al. (2011) argue that innovation performance is about how far a new product achieve its financial and sales target.

This study defines the construct of innovation performance as the significant new product, process, marketing, and organisation implementation which is unnecessarily novel to the world; however, it should be new to the organisation. Therefore, innovation performance consists of four dimensions: 1. product innovation (ProdI), 2. process innovation (ProcI), 3. marketing innovation (MI), and 4. organisational innovation (OI).

\subsection{Relationship between dynamic capabilities and intellectual capital}

Organisation operational capabilities consist of VRIN resources, organisational process and managerial decision (Teece et al. 1997). From the knowledge-based perspective, knowledge is the VRIN resource (Spender 1996, Spender and Grant 1996, Tiwana 2002, Wang 2014, Hussinki et al. 2017, Popa et al. 2017). Knowledge can be differentiated into knowledge stock or intellectual capital, and knowledge management (Kianto et al. 2014). Therefore, intellectual capital is a part of operational capabilities.

Operational capabilities or zero-level capability (Winter 2003) will not make organisation possess long-term competitive advantage (Ambrosini and Bowman 2009). Zerolevel capability will only enable the organisation to create the same product, scale and consumer all the time (Winter 2003). Therefore, the organisation needs dynamic capabilities (Teece et al. 1997, Zahra et al. 2006) to create, transform or enlarge its VRIN resources (Collis 1994, Ambrosini and Bowman 2009, Koryak et al. 2015, Battisti and Deakins 2017).

Activities of sensing business opportunities and threats through benchmarking and market survey (Cao 2011, Protogerou et al. 2011) will boost knowledge acquisition (Zahra and George 2002, Zahra et al. 2006). Once new knowledge has been acquired, it must undergo the validation process and be difused to people within organisations (Zahra et al. 1999), which in turn affect the quality of human capital, organisational/structural capital (Zahra et al. 1999, Koryak et al. 2015) and entrepreneurial capital of the organisation. Establishing contact with external parties through benchmarking and communicating with customers will enhance relational capital. Timely decision making, responding to customer expectation and implementing required change will also provide the learning opportunity that supports the renewal of intellectual capital elements. Thus, organisations with strong dynamic capabilities can enhance their intellectual capital (Koryak et al. 2015). The first hypothesis proposed is:

Hypothesis 1: Dynamic capabilities have a positive effect on intellectual capital.

\subsection{Relationship between intellectual capital and innovation performance}

Human knowledge and skill are crucial factors for innovation generation (Subramaniam and Youndt 2005). Creative and knowledgeable employees tend to generate new ideas (Anand et al. 2007), or question current routines run in the organisation (Amabile 1997). Therefore, the sum of skill and knowledge within the human is the predictor for innovation performance in the organisation (Kianto et al. 2017).

Structural capital, codified knowledge stock or experience affect innovation performance due to products, process or new method integrate varies of current knowledge (Fleming and Sorenson 2004). Therefore, by having organisational memory (Walsh and Ungson 1991), organisation will be able to combine previous experience to generate intended innovation.

Since the organisation does not have all knowledge needed for innovation, then it needs to acquire knowledge from external parties. In facts, many breakthrough innovation transplant organisations from one to another 
(Hargadon 2003). In general, collaboration with the external organisation will facilitate knowledge sharing, interactive learning and support innovation (Pérez-Luño et al. 2011). In this way, relational capital drives the innovation performance. Therefore, people can expect that intellectual capital will promote innovation performance. The next proposed hypothesis is:

Hypothesis 2: Intellectual capital has a positive effect on innovation performance.

\subsection{Relationship between dynamic capabilities and innovation performance}

Dynamic capabilities are very crucial for innovation creation (Giniuniene and Jurksiene 2015). The innovation processes engage operational capabilities and resources in the inputs, process and outputs chain (Lin et al. 2016). Dynamic capabilities update, integrate, and reconfigure current operational capabilities and resources (Helfat and Peteraf 2003, Helfat et al. 2007, Helfat and Winter 2011). Operational capabilities will remain the same unless dynamic capabilities trigger them to change (Collis 1994, Winter 2003, Helfat and Winter 2011). In other words, the mobilisation of resources and capabilities happens as a response to opportunities and changes (Liao et al. 2009, Pavlou and El Sawy 2011). In this sense, dynamic capabilities support the organisational effort to develop new products and process in the intended time (Wu 2006). Consequently, organisational inability to change its resources base would undermine its effort to create new products (Danneels 2011). Empirical evidence shows that dynamic capabilities influence innovation in public listed companies, in Taiwan securities market (Hsu and Sabherwal 2012). The proposed hypothesis is:

Hypothesis 3: Besides its indirect through of intellectual capital, dynamic capabilities have a direct effect on innovation performance.

The figure below (Figure 1) describes the research model of the study:

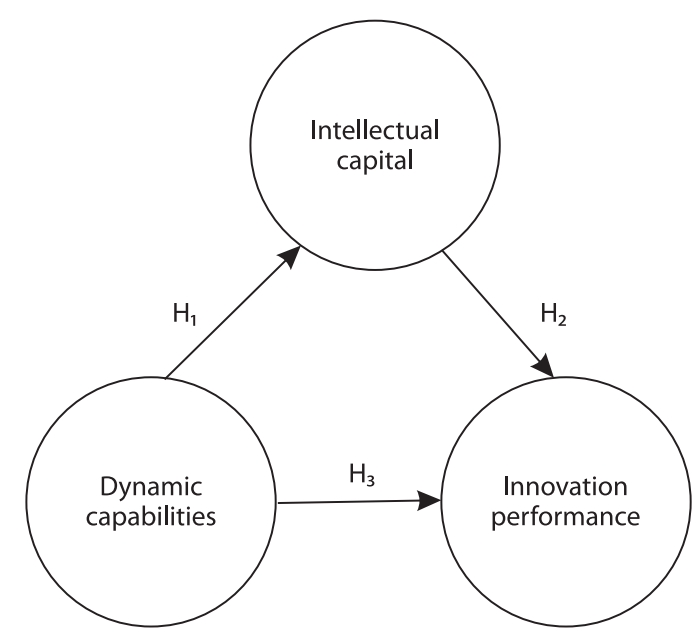

Figure 1. Research model
The research model above illustrates that dynamic capabilities are considered to have an indirect influence on innovation performance through intellectual capital. Moreover, dynamic capabilities also have a direct influence on innovation performance.

\section{Research methodology}

\subsection{Sample and data collection}

This study conducted in the SMEs of garment manufacturing in West Java Province, Indonesia. The organisation is the analysis unit. The observation unit is business owners/ director/senior manager. This study follows The Indonesian Central Bureau of Statistics (2018) SMEs categorisation. Small enterprise is a company with 2-19 employees, while medium enterprise is a company with 20-99 employees (The Indonesian Central Bureau of Statistics 2018). According to the Industry and Commerce Department of West Java Province, Indonesia, the population of SMEs garment manufacturing in this province was 4,873 companies. As suggested by Hair Jr et al. (2016), this study employs power analyses using $G^{\star}$ Power software to determine the minimum sample. The test family taken is $\mathrm{F}$ tests of a linier multiple regression. Power analysis type conducted is a priori. To detect effect size $\mathrm{f}^{2}$ values at 0.15 , a statistical significance level ( $\alpha$ error probability) of $1 \%$ and statistical power $99 \%$, and the $\mathrm{G}^{\star}$ Power software generated 219 minimum sample.

The questionnaire is the main instrument for primary data collection. Books, journals and other related records provide secondary data. Accidental and snowball sampling are two sampling techniques implemented. Those techniques were chosen due to the population distribution cover a large area with no sampling frame available. The final number of organisations involved in this study is 297, which is higher than the required minimal sample number.

\subsection{Measures}

Construct measurements consist of a 5-point multiple rating list scale as suggested by Cooper and Schindler (2014). Dynamic capabilities have three dimensions and seven indicators, in which the items were adapted from $\mathrm{Li}$ and Liu (2014), Cao (2011), Rufaidah and Sutisna (2015), Protogerou et al. (2011) studies. Intellectual capital was made up of four dimensions and thirteen indicators, in which the items were adapted from Engelman et al. (2017), Ramadan et al. (2017), Agostini et al. (2017), Hussinki et al. (2017), Inkinen et al. (2017), and Vera and Crossan (2005). Innovation performance consists of four dimensions and twelve indicators adapted from OECD (2005) and AlcaideMarzal and Tortajada-Esparza (2007). Complete dimensions and indicators applied in this study that were used to measure dynamic capabilities along with intellectual 
capital, and innovation performance are presented in Table 1.

Table 1. Variables, dimension and indicators of the study

\begin{tabular}{|c|c|c|}
\hline Variables & Dimensions & Indicators \\
\hline \multirow{7}{*}{$\begin{array}{l}\text { Dynamic } \\
\text { Capabilities }\end{array}$} & \multirow{3}{*}{$\begin{array}{l}\text { Strategic } \\
\text { Sensing (SS) }\end{array}$} & Effective benchmarking \\
\hline & & $\begin{array}{l}\text { Internal meetings to discuss the } \\
\text { market demand }\end{array}$ \\
\hline & & Market survey \\
\hline & \multirow{2}{*}{$\begin{array}{l}\text { Decision } \\
\text { Making (DM) }\end{array}$} & $\begin{array}{l}\text { Quick deal with conflict in } \\
\text { decision making process }\end{array}$ \\
\hline & & $\begin{array}{l}\text { Timely response to customer } \\
\text { complaint }\end{array}$ \\
\hline & \multirow{2}{*}{$\begin{array}{l}\text { Change Imple- } \\
\text { mentation (CI) }\end{array}$} & Proper award system \\
\hline & & Proper controlling system \\
\hline \multirow{13}{*}{$\begin{array}{l}\text { Intellectual } \\
\text { Capital }\end{array}$} & \multirow{4}{*}{$\begin{array}{l}\text { Human Capital } \\
\text { (HC) }\end{array}$} & Employee experience \\
\hline & & Employee skill \\
\hline & & New approaches to problem \\
\hline & & $\begin{array}{l}\text { Unanticipated events manage- } \\
\text { ment }\end{array}$ \\
\hline & \multirow{2}{*}{$\begin{array}{l}\text { Structural } \\
\text { Capital (SC) }\end{array}$} & Written procedure \\
\hline & & Knowledge documentation \\
\hline & \multirow{4}{*}{$\begin{array}{l}\text { Relational } \\
\text { Capital (RC) }\end{array}$} & $\begin{array}{l}\text { Partnership with market and } \\
\text { commercial }\end{array}$ \\
\hline & & Partnership with public sector \\
\hline & & $\begin{array}{l}\text { Partnership with community/ } \\
\text { association }\end{array}$ \\
\hline & & Information quantity \\
\hline & \multirow{3}{*}{$\begin{array}{l}\text { Entre- } \\
\text { preneurial } \\
\text { Capital (EC) }\end{array}$} & Courage to take deliberate risk \\
\hline & & $\begin{array}{l}\text { Courage to make bold and } \\
\text { difficult decision }\end{array}$ \\
\hline & & $\begin{array}{l}\text { Ability to identify business } \\
\text { opportunities }\end{array}$ \\
\hline \multirow{12}{*}{$\begin{array}{l}\text { Innovation } \\
\text { Perfor- } \\
\text { mance }\end{array}$} & \multirow{3}{*}{$\begin{array}{l}\text { Product } \\
\text { Innovation } \\
\text { (ProdI) }\end{array}$} & New materials \\
\hline & & New appearance \\
\hline & & New unique design \\
\hline & \multirow{3}{*}{$\begin{array}{l}\text { Process } \\
\text { Innovation } \\
\text { (ProcI) }\end{array}$} & New production method \\
\hline & & New equipment \\
\hline & & $\begin{array}{l}\text { New logistic/distribution/de- } \\
\text { livery }\end{array}$ \\
\hline & \multirow{4}{*}{$\begin{array}{l}\text { Marketing } \\
\text { Innovation } \\
(\mathrm{MI})\end{array}$} & New packaging \\
\hline & & New product placement \\
\hline & & $\begin{array}{l}\text { New promotion media/tech- } \\
\text { niques }\end{array}$ \\
\hline & & New pricing method \\
\hline & \multirow{2}{*}{$\begin{array}{l}\text { Organisational } \\
\text { Innovation } \\
(\mathrm{OI})\end{array}$} & New workplace organisation \\
\hline & & New external relations \\
\hline
\end{tabular}

\subsection{Data analysis method}

The analysis of descriptive data was used Microsoft Excel 2007 and the hypotheses testing used partial least squares (PLS) method with SmartPLS software, version 3.2.7. The present study adopts PLS because it does not call for multivariate normal data (Chin 1998).

\section{Results}

\subsection{Respondent description}

Based on the questionnaire, the majority (87\%) of organisations involved in this study were small organisations, which has been operating for at least five years (78\%). Mostly, employees' highest education level was junior high school (44\%). Males are $68 \%$ of the respondents. The highest percentage of respondents' last education level was the elementary school (36\%). The largest proportion of respondents with age range of $41-50$ years old was $38 \%$. The biggest percentage of respondents' position was business owners (94\%). Lastly, the largest proportion of respondents' similar business experience was 50\% (more than 9-years experience).

\subsection{Validity and reliability}

PLS analysis consists of two sub-models: 1 . measurement model, 2. structural model. The measurement model shows how manifested/observed variables represent latent variables. The structural model describes the estimation from one variable to other variables. Second order confirmatory factor analysis of this study uses repeated indicators approach as suggested by Wold (1982).

In PLS method, validity tests of the instrument is made up of convergent and discriminant validity. Convergent validity test uses factor loadings and the average variance explained (AVE) values. The instrument has an acceptable convergent validity whenever factor loadings are higher than 0.5 (Hair et al. 2010), and AVE values are above 0.5 (Fornell and Larcker 1981, Bagozzi et al. 1991). Discriminant validity was measured by using the square root of AVE. As the rule of thumb, discriminant validity exists whenever the value of square root of AVE is higher than other factors correlation (Fornell and Larcker 1981).

Reliability test uses composite reliability (CR) and Cronbach's alpha. According to Nunnally (1967), Cronbach's alpha coefficient value above 0.6 is considered to be acceptable. However, Peterson and Kim (2013) said that CR should be used as an alternative to Cronbach's alpha as Cronbach's alpha value is slightly lower than CR while the difference is relatively insignificant. When the $\mathrm{CR}$ is greater than 0.7 , it suggests good reliability of the latent variables (Chin 2010). Results of validity and reliability analysis are presented in the tables below. 
Table 2. Convergent validity and reliability of first-order factors

\begin{tabular}{|l|c|c|c|c|c|c|}
\hline \multicolumn{1}{|c|}{ Dimensions } & Indicators & $\begin{array}{c}\text { Factor } \\
\text { loadings }\end{array}$ & AVE & $\begin{array}{c}\text { Composite } \\
\text { reliability }\end{array}$ & $\begin{array}{c}\text { Cronbach's } \\
\text { alpha }\end{array}$ & $\mathrm{R}^{2}$ \\
\hline Strategic Sensing (SS) & 3 & $0.769-0.804$ & 0.626 & 0.834 & 0.701 & 0.610 \\
\hline Decision Making (DM) & 2 & $0.757-0.857$ & 0.654 & 0.790 & 0.475 & 0.616 \\
\hline Change Implementation (CI) & 2 & $0.904-0.917$ & 0.829 & 0.907 & 0.794 & 0.606 \\
\hline Human Capital (HC) & 4 & $0.722-0.804$ & 0.594 & 0.854 & 0.771 & 0.660 \\
\hline Structural Capital (SC) & 2 & $0.801-0.849$ & 0.681 & 0.810 & 0.533 & 0.635 \\
\hline Relational Capital (RC) & 4 & $0.695-0.845$ & 0.626 & 0.869 & 0.799 & 0.568 \\
\hline Entrepreneurial Capital (EC) & 3 & $0.769-0.873$ & 0.675 & 0.862 & 0.758 & 0.624 \\
\hline Product Innovation (ProdI) & 3 & $0.725-0.836$ & 0.593 & 0.813 & 0.655 & 0.675 \\
\hline Process Innovation (ProcI) & 3 & $0.829-0.865$ & 0.708 & 0.879 & 0.794 & 0.713 \\
\hline Marketing Innovation (MI) & 4 & $0.652-0.853$ & 0.599 & 0.855 & 0.770 & 0.840 \\
\hline Organisational Innovation(OI) & 2 & 0.862 & 0.743 & 0.852 & 0.654 & 0.590 \\
\hline
\end{tabular}

Note: All loadings are significant at level $\mathrm{p}<.001$ with 500 samples bootstrapping procedure. AVE $=$ average variance explained. $\mathrm{R}^{2}=\mathrm{R}$ square.

Table 3. Validity and reliability of second-order factors

\begin{tabular}{|l|c|c|c|c|c|c|}
\hline \multicolumn{1}{|c|}{ Variables } & Dimensions & $\begin{array}{c}\text { Factor } \\
\text { Loadings }\end{array}$ & AVE & $\begin{array}{c}\text { Composite } \\
\text { reliability }\end{array}$ & $\begin{array}{c}\text { Cronbach's } \\
\text { Alpha }\end{array}$ & $\mathrm{R}^{2}$ \\
\hline Dynamic Capabilities & 3 & $0.778-0.785$ & 0.781 & 0.825 & 0.770 & - \\
\hline Intellectual Capital & 4 & $0.754-0.812$ & 0.788 & 0.868 & 0.870 & 0.314 \\
\hline Innovation Performance & 4 & $0.768-0.917$ & 0.838 & 0.905 & 0.895 & 0.567 \\
\hline
\end{tabular}

Note: $\mathrm{AVE}=$ average variance explained. $\mathrm{R}^{2}=\mathrm{R}$ square.

Table 2 shows the convergent validity and reliability of first-order factors. All factor loadings and AVE of dimensions values were higher than 0.5 . Since all factor loadings and AVE values were above their threshold value, thus the measurements had good convergent validity. Table 1 also exhibits that Cronbach's alpha range from 0.475 to 0.799 . There were two dimensions with Cronbach's alpha value below 0.6. However, since all CR values were more significant than 0.7 , thus the instrument was reliable.

Table 3 presents the result of coefficient calculation through bootstrapping procedure for the second-order factors. All factor loadings of dimensions were higher than 0.7 and AVE above 0.5. Therefore, the instrument had good convergent validity. Table 3 also provides the information that CR and Cronbach's alpha were higher than 0.6 and 0.7 respectively, meaning that the second-order factors had acceptable reliability.

Table 4 presents that the square root of AVE was more significant than correlation values of latent variables. By using this criterion, the results in Table 4 suggest that the instrument fulfilled the requirement for discriminant validity.

\subsection{Hypotheses testing}

Hypotheses testing include path coefficients $(\beta)$ and T-Statistics, direct and indirect effects. The path model is depicted in Figure 2.

\section{Direct Effects}

The results support the hypotheses testing of this study. $\mathrm{H} 1$ predicts that there is a direct effect of dynamic capabilities on intellectual capital. As provided in Table 5, this study presents that dynamic capabilities had a significant positive effect on intellectual capital $(\beta=0.560, t=8.750)$. $\mathrm{H} 2$ predicts intellectual capital has a direct effect on innovation performance. The result reveals that intellectual capital's effect on innovation performance was positive and significant $(\beta=0.530, \mathrm{t}=8.259)$.

\section{The mediating effect of intellectual capital}

This paper hypothesise that intellectual capital has a partial mediating effect on dynamic capabilities and innovation performance relationship (H3). A partial mediating effect 
Table 4. Correlation and Discriminant Validity of second-order factors

\begin{tabular}{|c|c|c|c|c|c|c|c|c|c|c|c|c|}
\hline No & Dimensions & 1 & 2 & 3 & 4 & 5 & 6 & 7 & 8 & 9 & 10 & 11 \\
\hline 1 & Strategic Sensing (SS) & $0.791^{\mathrm{a}}$ & & & & & & & & & & \\
\hline 2 & Decision Making (DM) & 0.460 & 0.808 & & & & & & & & & \\
\hline 3 & $\begin{array}{l}\text { Change Implementation } \\
\text { (CI) }\end{array}$ & 0.324 & 0.271 & 0.911 & & & & & & & & \\
\hline 4 & Human Capital (HC) & 0.478 & 0.381 & 0.382 & 0.771 & & & & & & & \\
\hline 5 & Structural Capital (SC) & 0.230 & 0.260 & 0.279 & 0.508 & 0.825 & & & & & & \\
\hline 6 & Relational Capital (RC) & 0.315 & 0.098 & 0.388 & 0.387 & 0.613 & 0.791 & & & & & \\
\hline 7 & $\begin{array}{l}\text { Entrepreneurial Capital } \\
(\mathrm{EC})\end{array}$ & 0.391 & 0.565 & 0.471 & 0.610 & 0.532 & 0.351 & 0.822 & & & & \\
\hline 8 & $\begin{array}{l}\text { Product Innovation } \\
\text { (ProdI) }\end{array}$ & 0.412 & 0.404 & 0.544 & 0.512 & 0.357 & 0.407 & 0.520 & 0.770 & & & \\
\hline 9 & $\begin{array}{l}\text { Process Innovation } \\
(\text { ProcI })\end{array}$ & 0.279 & 0.346 & 0.572 & 0.330 & 0.308 & 0.479 & 0.411 & 0.628 & 0.842 & & \\
\hline 10 & $\begin{array}{l}\text { Marketing Innovation } \\
(\mathrm{MI})\end{array}$ & 0.384 & 0.279 & 0.529 & 0.444 & 0.518 & 0.657 & 0.475 & 0.658 & 0.668 & 0.774 & \\
\hline 11 & $\begin{array}{l}\text { Organisational } \\
\text { Innovation (OI) }\end{array}$ & 0.323 & 0.296 & 0.370 & 0.418 & 0.619 & 0.552 & 0.485 & 0.497 & 0.503 & 0.688 & 0.862 \\
\hline
\end{tabular}

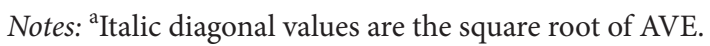

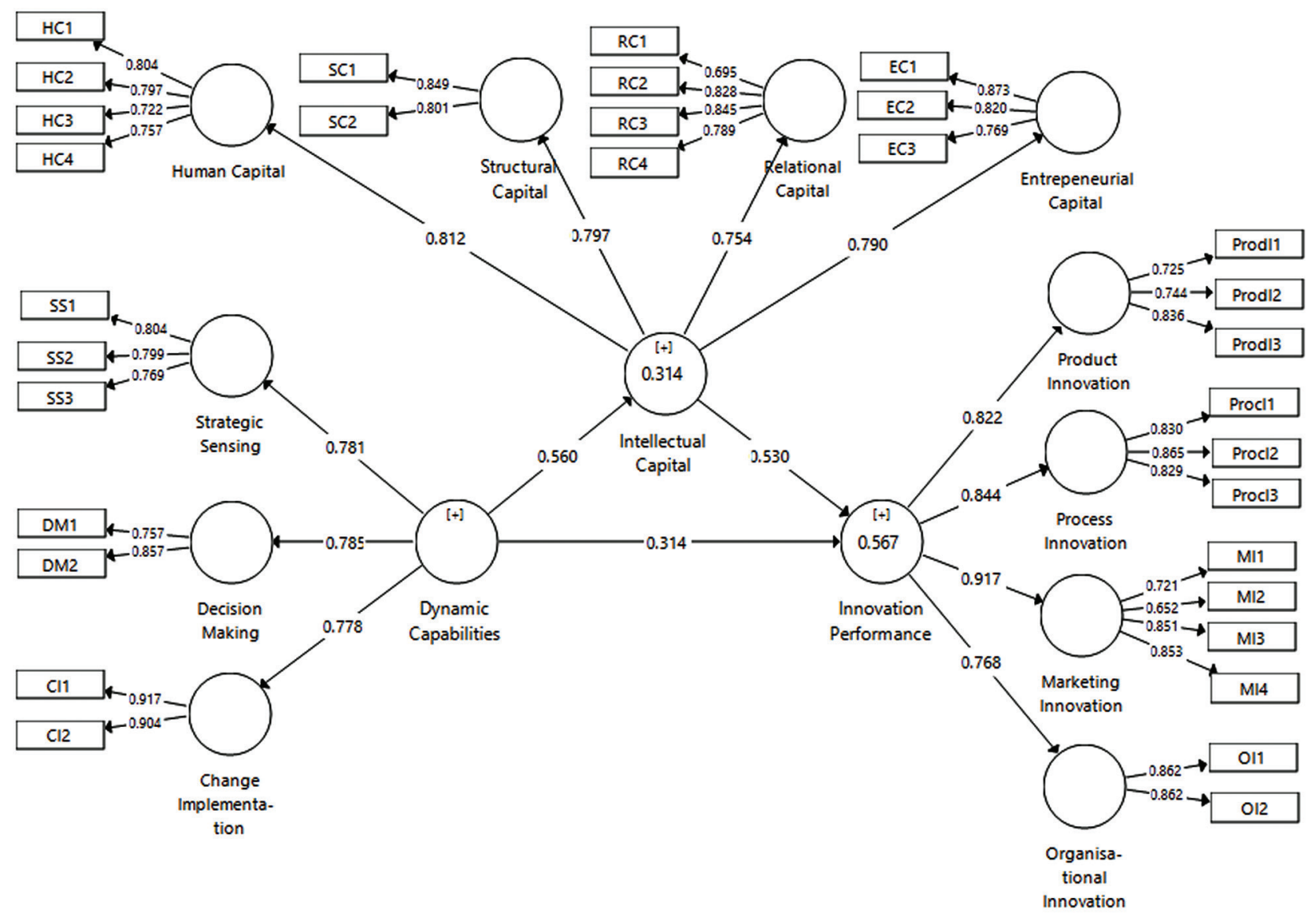

Figure 2. Path model 
Table 5. PLS structural model summary

\begin{tabular}{|l|c|c|c|c|}
\hline \multirow{2}{*}{\multicolumn{1}{|c|}{ Dimensions and Hypothesis }} & \multicolumn{2}{c|}{ Direct effects } & \multicolumn{2}{c|}{ Partial mediation } \\
\cline { 2 - 5 } & $\begin{array}{c}\text { Path } \\
\text { coefficient }(\beta)\end{array}$ & T-Statistics & $\begin{array}{c}\text { Path coefficient } \\
(\beta)\end{array}$ & T-Statistics ${ }^{\star a}$ \\
\hline H1: Dynamic capabilities -> Intellectual capital & 0.560 & 8.750 & - & - \\
\hline H2: Intellectual capital -> Innovation performance & 0.530 & 8.259 & - & - \\
\hline H3: Dynamic capabilities -> Innovation performance & 0.610 & 13.403 & 0.314 & 5.135 \\
\hline
\end{tabular}

Note: ${ }^{\star}$ Significant level at $\mathrm{p}<.001 .{ }^{\mathrm{a}} \mathrm{T}$-statistics obtained with 500 samples bootstrapping procedure.

takes place whenever the mediator variables involvement reduces the previous significant relationship of the exogenous and the endogenous variables. However, if the relationship between the exogenous and the endogenous variables becomes insignificant, the full mediation occurs. In order to test this intellectual capital mediating effects, this study follows Baron and Kenny (1986) mediation test steps:

- The exogenous variable significantly influences the mediating variable.

- The exogenous variable significantly influences the endogenous variable.

- The significant influence of the exogenous variable on the endogenous variable is reduced whenever the mediating variable included in the calculation.

Table 5 presents the result of mediating test, as follows:

- Dynamic capabilities significantly influenced intellectual capital $(\beta=0.560, t=8.750)$

- Dynamic capabilities significantly influenced innovation performance $(\beta=0.610, t=13.403)$.

- The dynamic capabilities significant influence on innovation performance was reduced $(\beta=0.314$, $\mathrm{t}=5.135)$ at the time intellectual capital included in the calculation.

Therefore, this finding supports $\mathrm{H} 3$ that intellectual capital partially mediated dynamic capabilities and innovation performance relationship.

\section{Discussion}

Limited studies are revealing the link between dynamic capabilities and intellectual capital in respect of innovation performance. This study aims at understanding the way dynamic capabilities influence innovation performance through the mediation of intellectual capital in Indonesian SME garment manufacturing. Results are expected to contribute to the existing literature and to the practical arena.

\subsection{Theoretical contributions}

Theoretical contributions of the study are as follows: Firstly, the result suggests dynamic capabilities had a significant positive influence on and intellectual capital. The finding contributes to the dynamic capabilities literature by positioning intellectual capital as the output of dynamic capabilities. The result extends the conceptual framework proposed by Ambrosini and Bowman (2009) and Koryak et al. (2015) by providing empirical evidence discovering that the resources base is the output of dynamic capabilities. This study provides a different perspective on considering the link of dynamic capabilities and intellectual capital. Meanwhile, previous studies favour for intellectual capital as the predictor of dynamic capabilities (e.g. Hsu and Sabherwal 2012, Hsu and Wang 2012, Singh and Rao 2016), the result shows that intellectual capital was affected by dynamic capabilities. The finding implies that dynamic capabilities could renew the stock of knowledge within the organisations. Based on this study calculation, as much as $31.4 \%$ variations in intellectual capital were affected by dynamic capabilities (see Table 3).

Secondly, by examining intellectual capital and innovation performance interaction, it has been found that intellectual capital positively and significantly affected innovation performance. The result is consistent with prior research by Subramaniam and Youndt (2005) and Kianto et al. (2017) that intellectual capital predicted innovation performance. Knowledgeable employees, supporting knowledge infrastructure and good relationship with external parties, will facilitate the ideation and implementation of innovation within the organisation (Dost et al. 2016). This finding strengthens the position of intellectual capital as the predictor of innovation in the management literature.

Thirdly, this study also reveals that intellectual capital was partially mediated dynamic capabilities and innovation performance relationship. Previous literature only favours for dynamic capabilities role as the mediator (See: Hsu and Sabherwal 2012, Han and Li 2015) or the moderator (See: Wu et al. 2007) on intellectual capital influence to innovation performance. However, this study reveals that the way dynamic capabilities influence innovation performance was partially through affecting the intellectual capital. This finding support Protogerou et al. (2011) and Ambrosini and Bowman (2009) that operational capabilities mediated dynamic capabilities' influence on organisational outcomes. Dynamic capabilities are essential predictors, 
but by themselves are insufficient to enhance innovation performance. Hence, this study offers a new theoretical perspective on considering the link of dynamic capabilities, intellectual capital and innovation performance in the academic discussion.

\subsection{Practical contributions}

Regarding practical contributions, this study offers empirical evidence to business owners/directors/managers in the SMEs garment manufacturing that dynamic capabilities activities conducted by organisations will likely affect the quality of intellectual capital and in turns affecting organisational innovation performance. Assessing the environmental dynamics that concerns opportunities and threats existed through strategic sensing are central to new knowledge acquired by organisations. Newly gained knowledge will enhance human, structural capital and entrepreneurial. Establishing contact with external parties, such as competitor and consumers, will augment relational capital. Taking timely decision-making and implementing required changes provide learning opportunity that supports the renewal of intellectual capital elements. Then, qualified intellectual capital will support the idea generation and implementation of product, process, marketing, and organisational innovation. Therefore, investing times and efforts in the dynamic capabilities' activities may result in the desired intellectual capital and innovation outcomes as expected by organisations.

\section{Limitations and future research}

This study has integrated dynamic capabilities, intellectual capital and innovation performance in one research model as the novelty of the research. However, the study still needs further investigation. First, this study involved business owners, directors, and managers as informants. Even though their evaluations might represent organisational management practice, their subjective assessment may differ from what employee experience. Future studies are suggested to involve employee in order to have a more comprehensive understanding of the proposed hypotheses.

Second, future studies need to integrate other mediating or moderating variables from the knowledge-based view (KBV) perspective, such as knowledge management, organisational learning, learning orientation or learning styles in their research model. Previous organisational learning and knowledge management studies conclude that both variables influenced organisational performance significantly (Purwihartuti et al. 2015). Thus, it will help us to have more wide-ranging knowledge on innovation performance drivers.

Third, this study took place in the SMEs of garment manufacturing in Indonesia. Future research should test the research model in different firm size, other industries and a different national context with unique characteristics, in order to create generalisation in this research field.

\section{Conclusions}

Previous scholarly discussions tend to argue that dynamic capabilities are the mediating or moderating variable in intellectual capital and innovation performance causal relationship. Meanwhile, this study seeks to offer a new perspective and provides empirical evidence that dynamic capabilities are predictors of innovation performance through the partial mediation of intellectual capital in SMEs of garment manufacturing. Dynamic capabilities can directly encourage innovation performance and/or through intellectual capital. Hence, it is highly recommended to business owners/directors/managers of SMEs garment manufacturing to build up, implement, and maintain their dynamic capabilities, hence, the intellectual capital and innovation performance of their organisations can achieve the intended level. Future studies on the interactive effect of dynamic capabilities, intellectual capital and innovation performance from employees and the knowledge-based view perspective in different firm size, industries and national context are suggested to be conducted to build a fruitful research area and discussion.

\section{Author contributions}

Below are the authors' contributions to this study:

- Wendra Wendra writes the first draft of the article, collects data and writes the final article.

- Ernie Tisnawati Sule validates the final draft of the article.

- Joeliaty Joeliaty analyses and interprets the data acquired.

- Yudi Azis validates the research methodology and questionnaires preparation.

\section{Disclosure statement}

Authors do not have any competing financial, professional, or personal interests from other parties.

\section{References}

Agostini L, Nosella A, Filippini R (2017) Does intellectual capital allow improving innovation performance? A quantitative analysis in the sme context. Journal of Intellectual Capital 18 (2): 400-418. http://doi.org/10.1108/JIC-05-2016-0056

Alcaide-Marzal J, Tortajada-Esparza E (2007) Innovation assessment in traditional industries. A proposal of aesthetic innovation indicators. Scientometrics 72 (1): 33-57. http:// doi.org/10.1007/s11192-007-1708-X 
Amabile TM (1997) Motivating creativity in organizations: on doing what you love and loving what you do. California Management Review 40 (1):39-58. http://doi.org/10.2307/41165921

Ambrosini V, Bowman C (2009) What are dynamic capabilities and are they a useful construct in strategic management? International Journal of Management Reviews 11 (1): 29-49. http://doi.org/10.1111/j.1468-2370.2008.00251.x

Anand N, Gardner HK, Morris T (2007) Knowledge-based innovation: emergence and embedding of new practice areas in management consulting firms. Academy of Management Journal 50 (2): 406-428. http://doi.org/10.5465/ amj.2007.24634457

Anderson N, Potočnik K, Zhou J (2014) Innovation and creativity in organizations: a state-of-the-science review, prospective commentary, and guiding framework. Journal of Management 40 (5): 1297-1333. http://doi. org/10.1177/0149206314527128

Ansari R, Barati A, Sharabiani AAA (2016) The role of dynamic capability in intellectual capital and innovative performance. International Journal of Innovation and Learning 20 (1): 47 67. http://doi.org/10.1504/IJIL.2016.076671

Azis Y, Darun MR, Kartini D, Bernik M, Harsanto B (2017) A model of managing innovation of smes in Indonesian creative industries. International Journal of Business and Society 18 (2): 391-408. http://www.ijbs.unimas.my/images/repository/ pdf/Vol18-S2-paper10.pdf

Azis Y, Kartini D, Bernik M, Harsanto B (2014) Managing innovation in creative industries for increasing competitiveness: case study of companies at Bandung - Indonesia. International Journal of Innovative Research in Science, Engineering and Technology (3): 11. http://doi.org/10.15680/ IJIRSET.2014.0311064

Babelytė-Labanauskė K, Nedzinskas Š (2017) Dynamic capabilities and their impact on research organizations' R\&D and innovation performance. Journal of Modelling in Management 12 (4): 603-630. http://doi.org/10.1108/jm2-05-2015-0025

Bagozzi RP, Yi Y, Phillips LW (1991) Assessing construct validity in organizational research. Administrative Science Quarterly 421-458. http://doi.org/10.2307/2393203

Baron RM, Kenny DA (1986) The moderator-mediator variable distinction in social psychological research: conceptual, strategic, and statistical considerations. Journal of personality and social psychology 51 (6): 1173. http://doi.org/10.1037/00223514.51.6.1173

Barreto I (2010) Dynamic capabilities: a review of past research and an agenda for the future. Journal of Management 36 (1): 256-280. http://doi.org/10.1177/0149206309350776

Battisti M, Deakins D (2017) The relationship between dynamic capabilities, the firm's resource base and performance in a post-disaster environment. International Small Business Journal 35 (1): 78-98. http://doi.org/10.1177/0266242615611471

Breznik L, Hisrich RD (2014) Dynamic capabilities vs innovation capability: are they related? Journal of Small Business and Enterprise Development 21 (3): 368-384. http://doi.org/10.1108/ jsbed-02-2014-0018

Bruce M, Daly L, Towers N (2004) Lean or agile: a solution for supply chain management in the textiles and clothing industry? International Journal of Operations \& Production Management 24 (2): 151-170. http://doi. org/10.1108/01443570410514867
Buenechea-Elberdin M (2017) Structured literature review about intellectual capital and innovation. Journal of Intellectual Capital 18 (2): 262-285. http://doi.org/10.1108/jic-07-20160069

Bueno E, Paz Salmador M, Rodríguez Ó (2004) The role of social capital in today's economy: empirical evidence and proposal of a new model of intellectual capital. Journal of Intellectual Capital 5 (4): 556-574. http://doi. org/10.1108/14691930410567013

Cabrita MDR, Bontis N (2008) Intellectual capital and business performance in the Portuguese banking industry. International Journal of Technology Management 43 (1-3): 212-237. http://doi.org/10.1504/ijtm.2008.019416

Cao L (2011) Dynamic capabilities in a turbulent market environment: empirical evidence from international retailers in China. Journal of Strategic Marketing 19 (5): 455-469. http:// doi.org/10.1080/0965254X.2011.565883

Castro GM-d, Delgado-Verde M, Amores-Salvadó J, Navas-López JE (2013) Linking human, technological, and relational assets to technological innovation: exploring a new approach. Knowledge Management Research \& Practice 11 (2): 123-132. http://doi.org/10.1057/kmrp.2013.8

Chen M-C, Cheng S-J, Hwang Y (2005) An empirical investigation of the relationship between intellectual capital and firms' market value and financial performance. Journal of Intellectual Capital 6 (2): 159-176. http://doi. org/10.1108/14691930510592771

Chien SY, Tsai CH (2012) Dynamic capability, knowledge, learning, and firm performance. Journal of Organizational Change Management 25 (3): 434-444. http://doi. org/10.1108/09534811211228148

Chin WW (1998) The partial least squares approach to structural equation modeling. In: Marcoulides GA (Ed) Modern methods for business research. Mahwah, NJ: Lawrence Erlbaum Associates, 295-336.

Chin WW (2010) How to write up and report PLS analysis. In: Vinzi VE, Chin WW, Henseler J, Wang H (Eds) Handbook of partial least squares: Concepts, methods and applications. Heidelberg, Berlin: Springer-Verlag, 655-690. http://link. springer.com/chapter/10.1007\%2F978-3-540-32827-8_29

Collis DJ (1994) Research note: how valuable are organizational capabilities? Strategic Management Journal 15 (S1): 143-152. http://doi.org/10.1002/smj.4250150910

Cooper DR, Schindler PS (2014) Business research methods (12 ed). New York: McGraw-Hill International Edition.

Danneels E (2002) The dynamics of product innovation and competences. Journal of Strategic Management 23 (12): 10951121. http://doi.org/10.1002/smj.275

Danneels E (2008) Organizational antecedents of second-order competences. Strategic Management Journal 29 (5): 519-543. http://doi.org/10.1002/smj.684

Danneels E (2011) Trying to become a different type of company: dynamic capability at Smith Corona. Strategic Management Journal 32 (1): 1-31. http://doi.org/10.1002/smj.863

Dost M, Badir YF, Ali Z, Tariq A (2016) The impact of intellectual capital on innovation generation and adoption. Journal of Intellectual Capital 17 (4): 675-695. http://doi.org/10.1108/ JIC-04-2016-0047 
du Plessis M (2007) The role of knowledge management in innovation. Journal of Knowledge Management 11 (4): 20-29. http://doi.org/10.1108/13673270710762684

Edvinsson L, Malone M (1997) Intellectual capital: realizing your company's true value by finding its hidden brainpower. New York: Harper Business.

Eisenhardt KM, Martin JA (2000) Dynamic capabilities: what are they? Strategic Management Journal 21 (10-11): 1105-1121. https://doi.org/10.1002/1097-0266\%28200010/11\%2921\%3A1 0/11<1105\%3A\%3AAID-SMJ133>3.0.CO\%3B2-E

Engelman RM, Fracasso EM, Schmidt S, Zen AC (2017) Intellectual capital, absorptive capacity and product innovation. Management Decision 55 (3): 474-490. http://doi.org/10.1108/ md-05-2016-0315

Fleming L, Sorenson O (2004) Science as a map in technological search. Strategic Management Journal 25 (8-9): 909-928. http://doi.org/10.1002/smj.384

Fornell C, Larcker DF (1981) Evaluating structural equation models with unobservable variables and measurement error. Journal of Marketing Research, 39-50. http://doi. org/ $10.2307 / 3151312$

Fumi A, Pepe A, Scarabotti L, Schiraldi MM (2013) Fourier analysis for demand forecasting in a fashion company. International Journal of Engineering Business Management 5: 30. http:// doi.org/10.5772/56839

Giniuniene J, Jurksiene L (2015) Dynamic capabilities, innovation and organizational learning: Interrelations and impact on firm performance. Procedia - Social and Behavioral Sciences 213: 985-991. http://doi.org/10.1016/j.sbspro.2015.11.515

Gupta AK, Tesluk PE, Taylor MS (2007) Innovation at and across multiple levels of analysis. Organization Science 18 (6): 885897. http://doi.org/10.1287/orsc.1070.0337

Hair JF, Black WC, Babin BJ, Anderson RE (2010) Multivariate Data Analysis (7th ed). New Jersey: Pearson Prentice Hall.

Hair Jr JF, Hult GTM, Ringle C, Sarstedt M (2016) A primer on partial least squares structural equation modeling (PLS-SEM). Sage Publications.

Han Y, Li D (2015) Effects of intellectual capital on innovative performance: the role of knowledge-based dynamic capability. Management Decision 53 (1): 40-56. http://doi.org/10.1108/ md-08-2013-0411

Hargadon A (2003) How breakthroughs happen: the surprising truth about how companies innovate. Boston, MA: Harvard Business Press.

Helfat CE, Finkelstein S, Mitchell W, Peteraf MA, Singh H, Teece DJ, Winter SG (2007) Dynamic capabilities: understanding strategic change in organizations. Malden, MA: Blackwell Publishing.

Helfat CE, Peteraf MA (2003) The dynamic resource-based view: capability lifecycles. Strategic Management Journal 24 (10): 997-1010. http://doi.org/10.1002/smj.332

Helfat CE, Winter SG (2011) Untangling dynamic and operational capabilities: strategy for the $(\mathrm{N})$ ever-changing world. Strategic Management Journal 32 (11): 1243-1250. http://doi. $\operatorname{org} / 10.1002 /$ smj. 955

Hsu I-C, Sabherwal R (2012) Relationship between intellectual capital and knowledge management: an empirical investigation. Decision Sciences 43 (3). http://doi.org/10.1111/j.15405915.2012.00357.x
Hsu L-C, Wang C-H (2012) Clarifying the effect of intellectual capital on performance: the mediating role of dynamic capability. British Journal of Management 23 (2): 179-205. http:// doi.org/10.1111/j.1467-8551.2010.00718.x

Hussinki H, Ritala P, Vanhala M, Kianto A (2017) Intellectual capital, knowledge management practices and firm performance. Journal of Intellectual Capital 18 (4): 904-922. http:// doi.org/doi:10.1108/JIC-11-2016-0116

Inkinen H, Kianto A, Vanhala M, Ritala P (2017) Structure of intellectual capital - an international comparison. Accounting, Auditing \& Accountability Journal 30 (5): 1160-1183. http:// doi.org/10.1108/AAAJ-11-2015-2291

Iturrioz C, Aragón C, Narvaiza L (2015) How to foster shared innovation within SMEs' networks: Social capital and the role of intermediaries. European Management Journal 33: 104-115. http://doi.org/10.1016/j.emj.2014.09.003

Joeliaty J (2012) The influence of intellectual capital and knowledge management to competitive advantage and its impact on the performance of study program (A study on state universities in Bandung). PhD's Thesis, Indonesia: Universitas Padjadjaran.

Kapelko M, Oude Lansink A (2014) Examining the relation between intangible assets and technical efficiency in the international textile and clothing industry. The Journal of The Textile Institute 105 (5): 491-501. http://doi.org/10.1080/004 05000.2013 .826417

Khalique M, Bontis N, Nassir bin Shaari JA, Isa AHM (2015) Intellectual capital in small and medium enterprises in $\mathrm{Pa}$ kistan. Journal of Intellectual Capital 16 (1): 224-238. http:// doi.org/10.1108/jic-01-2014-0014

Kianto A, Antonio Lerro DRLD, Ritala P, Spender J-C, Vanhala M (2014) The interaction of intellectual capital assets and knowledge management practices in organizational value creation. Journal of Intellectual Capital 15 (3): 362-375. http:// doi.org/10.1108/jic-05-2014-0059

Kianto A, Sáenz J, Aramburu N (2017) Knowledge-based human resource management practices, intellectual capital and innovation. Journal of Business Research 81: 11-20. http://doi. org/10.1016/j.jbusres.2017.07.018

Koryak O, Mole KF, Lockett A, Hayton JC, Ucbasaran D, Hodgkinson GP (2015) Entrepreneurial leadership, capabilities and firm growth. International Small Business Journal 33 (1): 89-105. http://doi.org/10.1177/0266242614558315

Li D-y, Liu J (2014) Dynamic capabilities, environmental dynamism, and competitive advantage: Evidence from China. Journal of Business Research 67: 2793-2799. http://doi. org/10.1016/j.jbusres.2012.08.007

Liao J, Kickul JR, Ma H (2009) Organizational dynamic capability and innovation: an empirical examination of internet firms. Journal of Small Business Management 47 (3): 263-286. http:// doi.org/10.1111/j.1540-627X.2009.00271.X

Lin H-F, Su J-Q, Higgins A (2016) How dynamic capabilities affect adoption of management innovations. Journal of Business Research 69 (2): 862-876. http://doi.org/10.1016/j. jbusres.2015.07.004

Mačerinskienė I, Survilaite S (2011) Company's value added and its intellectual capital coherence. Business: Theory and Practice 12 (2): 183-192. http://doi.org/10.3846/btp.2011.19 
Marzo G, Stefano Zambon D, Scarpino E (2016) Exploring intellectual capital management in SMES: an in-depth Italian case study. Journal of Intellectual Capital 17 (1): 27-51. http://doi. org/10.1108/jic-09-2015-0075

Müller K, Rammer C, Trüby J (2009) The role of creative industries in industrial innovation. Innovation 11 (2): 148-168. http://doi.org/10.5172/impp.11.2.148

Nayak R, Padhye R (2015) Garment manufacturing technology. Cambridge, UK: Elsevier.

Nieto MJ, Santamaría L (2010) Technological collaboration: Bridging the innovation gap between small and large firms* Journal of Small Business Management 48 (1): 44-69. http:// doi.org/doi:10.1111/j.1540-627X.2009.00286.x

Nunnally JC (1967) Psychometric Theory (1st ed). New York: McGraw-Hill.

OECD (2005) Oslo Manual: Guidelines For collecting and interpreting innovation data (3rd ed). France: OECD Publishing.

Pavitt K (1984) Sectoral patterns of technical change: towards a taxonomy and a theory. Research Policy 13 (6): 343-373. http://doi.org/10.1016/0048-7333(84)90018-0

Pavlou PA, El Sawy OA (2011) Understanding the elusive black box of dynamic capabilities. Decision Sciences 42 (1): 239273. http://doi.org/10.1111/j.1540-5915.2010.00287.x

Penrose ET (1959) The theory of the growth of the firm. New York: Wiley.

Pérez-Luño A, Cabello Medina C, Carmona Lavado A, Cuevas Rodríguez G (2011) How social capital and knowledge affect innovation. Journal of Business Research 64 (12): 1369-1376. http://doi.org/10.1016/j.jbusres.2011.01.014

Peterson RA, Kim Y (2013) On the relationship between coefficient alpha and composite reliability. Journal of Applied Psychology 98 (1): 194. http://doi.org/10.1037/a0030767

Petty R, Guthrie J (2000) Intellectual capital literature review: measurement, reporting and management. Journal of Intellectual Capital 1 (2): 155-176. https://doi. org/10.1108/14691930010348731

Popa S, Soto-Acosta P, Martinez-Conesa I (2017) Antecedents, moderators, and outcomes of innovation climate and open innovation: an empirical study in SMEs. Technological Forecasting and Social Change 118: 134-142. http://doi. org/10.1016/j.techfore.2017.02.014

Protogerou A, Caloghirou Y, Lioukas S (2011) Dynamic capabilities and their indirect impact on firm performance. Industrial and Corporate Change 21 (3): 615-647. http://doi. org/10.1093/icc/dtr049

Purwihartuti K, Sule ET, Hilmiana, Muizu WOZ (2015) Organizational learning and knowledge management. Mediterranean Journal of Social Sciences 6 (5): 136-141. http://doi. org/10.5901/mjss.2015.v6n5s5p136

Ramadan BM, Dahiyat SE, Bontis N, Al-dalahmeh MA (2017) Intellectual capital, knowledge management and social capital within the ICT sector in Jordan. Journal of Intellectual Capital 18 (2): 437-462. http://doi.org/10.1108/jic-06-2016-0067

Rijsdijk SA, Langerak F, Jan Hultink E (2011) Understanding a two-sided coin: antecedents and consequences of a decomposed product advantage. Journal of Product Innovation Management 28 (1): 33-47. http://doi.org/10.1111/j.15405885.2010.00779.x
Rufaidah P, Sutisna (2015) Kapabilitas dinamis UMKM industri kreatif Jawa Barat. Sosiohumaniora 17 (1): 60-66. http://doi. org/10.24198/sosiohumaniora.v17i1.5674

Schumpeter J (1934) The theory of economic development - an inquiry into profits, capital, credit, interest, and the business cycle. Cambridge, MA: Harvard University Press.

Singh B, Rao MK (2016) Effect of intellectual capital on dynamic capabilities. Journal of Organizational Change Management 29 (2): 129-149. http://doi.org/10.1108/jocm-12-2014-0225

Spender J-C (1996) Making knowledge the basis of a dynamic theory of the firm. Strategic Management Journal 17 (Winter 1996): 45-63. http://doi.org/10.1002/smj.4250171106

Spender J-C, Grant RM (1996) Knowledge and the firm: overview. Strategic Management Journal 17 (Winter Special Issue): 5-9. http://doi.org/10.1002/smj.4250171103

Stengg W (2001) The textile and clothing industry in the EU. European Communities, Luxembourg http://ec.europa.eu/ search/?queryText=stengg\&query_source=GROWTH\&page $=1 \&$ filter $=\&$ swlang $=$ en \&filterSource $=$ GROWTH\&more_options_date $={ }^{*} \&$ more_options_language $=$ en $\&$ more_options_f formats ${ }^{*}$ \#

Subramaniam M, Youndt MA (2005) The influence of intellectual capital on the types of innovative capabilities. Academy of Management Journal 48 (3): 450-463. http://doi.org/10.5465/ amj.2005.17407911

Suroso E, Azis Y (2015) Defining mainstreams of innovation: a literature review. In: Proceedings of First International Conference on Economics and Banking (ICEB-15), Indonesia, 26-27 May 2014. http://doi.org/10.2991/iceb-15.2015.55

Survilaitė S, Tamošiūnienė R, Satrevics V (2015) Intellectual capital approach to modern management through the perspective of a company's value added. Business: Theory and Practice 16 (1): 31-44. http://doi.org/10.3846/btp.2015.553

Teece D (2007) Explicating dynamic capabilities: the nature and microfoundations of (sustainable) enterprise performance. Strategic Management Journal 28 (13): 1319-1350. http:// doi.org/10.1002/smj.640

Teece DJ (2009) Dynamic capabilities and strategic management: organizing for innovation and growth. Oxford: Oxford University Press.

Teece DJ, Pisano G, Shuen A (1997) Dynamic capabilities and strategic management. Strategic Management Journal 18 (7). https://doi.org/10.1002/(SICI)10970266(199708)18:7<509::AID-SMJ882>3.0.CO;2-Z

The Indonesian Central Bureau of Statistics. (2018). Manufacturing companies www.bps.go.id/subject/9/industri-besar-dansedang.html

Tiwana A (2002) The knowledge management toolkit: orchestrating IT strategy, and knowledge platforms (2nd ed). Upper Saddle River: Prentice-Hall.

Vera D, Crossan M (2005) Improvisation and innovative performance in teams. Organization Science 16 (3): 203-224. http:// doi.org/10.1287/orsc.1050.0126

Walsh JP, Ungson GR (1991) Organizational memory. Academy of Management Review 16 (1): 57-91. http://doi. org/10.2307/258607

Wang CL, Ahmed PK (2007) Dynamic capabilities: a review and research agenda. International Journal of Management Reviews 9 (1): 31-51. http://doi.org/10.1111/j.14682370.2007.00201.x 
Wang D, Chen S (2013) Does intellectual capital matter? Highperformance work systems and bilateral innovative capabilities. International Journal of Manpower 34 (8): 861-879. http://doi.org/10.1108/ijm-07-2013-0167

Wang H-L (2014) Theories for competitive advantage. In: Hasan $\mathrm{H}$ (Ed) Being practical with theory: a window into business research. Wollongong, Australia: lulu.com, 33-43.

Wang Y-S (2016) Dynamic capabilities in fashion apparel industry: emergent conceptual framework. Baltic Journal of Management 11 (3): 286-309. http://doi.org/10.1108/BJM02-2015-0051

Winter SG (2003) Understanding dynamic capabilities. Strategic Management Journal 24 (10): 991-995. http://doi.org/10.1002/ smj.318

Wold H (1982) Soft modeling: the basic design and some extensions. In: Jöreskog K, Wold H (Eds) Systems under indirect observation: Part I, 2: 1-54. Amsterdam: North-Holland.

Wu I-L, Chen JL (2014) Knowledge management driven firm performance: the roles of business process capabilities and organizational learning. Journal of Knowledge Management 18 (6): 1141-1164. http://doi.org/10.1108/jkm-05-2014-0192

Wu L-Y (2006) Resources, dynamic capabilities and performance in a dynamic environment: perceptions in Taiwanese IT enterprises. Information \& Management 43 (4): 447-454. http:// doi.org/https://doi.org/10.1016/j.im.2005.11.001
Wu SH, Lin LY, Hsu MY (2007) Intellectual capital, dynamic capabilities and innovative performance of organisations. International Journal of Technology Management 39 (3/4): 279. http://doi.org/10.1504/ijtm.2007.013496

Yuan HT, Joe S-W, Ding CG, Lin C-P (2013) Modeling technological innovation performance and its determinants: an aspect of buyer-seller social capital. Technological Forecasting and Social Change 80 (6): 1211-1221. http://doi.org/10.1016/j. techfore.2012.10.028

Zahra SA, George G (2002) Absorptive capacity: a review, reconceptualization and extension. Academy of Management Review 27 (2): 185-203. http://doi.org/10.2307/4134351

Zahra SA, Nielsen AP, Bogner WC (1999) Corporate entrepreneurship, knowledge, and competence development. Entrepreneurship Theory and Practice 23 (3): 169-189. http://doi. org/10.1177/104225879902300310

Zahra SA, Sapienza HJ, Davidsson P (2006) Entrepreneurship and dynamic capabilities: A review, model and research agenda* Journal of Management Studies 43 (4): 917-955. http://doi. org/10.1111/j.1467-6486.2006.00616.x

Zheng S, Zhang W, Du J (2011) Knowledge-based dynamic capabilities and innovation in networked environments. Journal of Knowledge Management 15 (6): 1035-1051. http://doi. org/10.1108/13673271111179352

Zollo M, Winter SG (2002) Deliberate learning and the evolution of dynamic capabilities. Organization Science 13 (3): 339-351. http://www.jstor.org/stable/3086025 